\title{
PENGARUH PERBANDINGAN NANAS (Ananas comosus L. Merr.) DAN SAWI HIJAU (Brassica juncea L.) TERHADAP KARAKTERISTIK SELAI
}

\author{
Tito Azhari Saputro ${ }^{1}$, I Dewa Gede Mayun Permana², Ni Luh Ari Yusasrini² \\ ${ }^{1}$ Mahasiswa Jurusan Ilmu dan Teknologi Pangan, Fakultas Teknologi Pertanian, Universitas Udayana \\ ${ }^{2}$ Dosen Jurusan Ilmu dan Teknologi Pangan, Fakultas Teknologi Pertanian, Universitas Udayana
}

Email : tito.azhari23@gmail.com

\begin{abstract}
The aim of this research was to know effect the ratio of pineapple and mustard greens to the characteristic of jam, and determine the best ratio made by those, to produce a good characteristic of jam. This research used Complete Random Design with the treatment comparison of pineapple and mustard green comprised of 5 (five) treatments, such as 100\% pineapple : 0\% mustard greens, $95 \%$ pineapple : $5 \%$ mustard greens, $90 \%$ pineapple : 10\% mustard greens, $85 \%$ pineapple : 15\% mustard greens, $80 \%$ pineapple : $20 \%$ mustard greens. All of treatments were repeated for 3 times to obtain 15 research units. Data were analyzed using analysis of variance and if an influences occurred among the treatments, the research would be continued to the Duncan's test. Results of this research had showed that the comparison ratio of pineapple and mustard greens gave influences to the water content, total sugar, total calcium, total soluble solid, viscosity, pH balance, texture, color, flavour, taste and overall acceptance of a jam. The best ratio of pineapple and mustard greens showed of percentage 90\% pineapple : $10 \%$ mustard greens with characteristics : $25,58 \%$ water content, $57,45 \%$ total sugar, 6.176 $\mathrm{mg} / 100 \mathrm{~g}$ calcium, 59,15\%brix total soluble solids, viscosity $64580 \mathrm{cps}, 4,65 \mathrm{pH}$, texture (very like), color (like), flavor (like), taste (very like) and overall acceptance (very like).
\end{abstract}

Keywords : pineapple, mustard greens, characteristic, jam.

\section{PENDAHULUAN}

Nanas adalah buah yang memiliki karakteristik khas dari segi aroma, rasa dan warna yang disukai sebagian besar masyarakat (Irfandi, 2005). Umumnya buah nanas hanya dikonsumsi dalam bentuk buah segar bukan dalam bentuk produk olahan. Nanas sangat mudah didapat dan jumlahnya melimpah karena masa panennya tidak mengenal musim, namun memiliki sifat mudah rusak dan cepat mengalami kebusukan (Kartika dan Nisa, 2015). Salah satu cara yang dapat dilakukan untuk mengatasinya adalah dengan mengolah nanas menjadi suatu produk olahan yaitu selai.

Selai merupakan makanan kental atau semi padat yang dibuat dari buah-buahan ditambah gula kemudian dipekatkan. Buah-buahan dan sayuran umumnya dapat diolah menjadi selai (Palupi et al., 2009). Selai biasa digunakan sebagai pelengkap roti, isian kue kering dan bahan tambahan pada produk pangan yang lain. Selai yang berasal dari buah-buahan pada umumnya hanya kaya akan vitamin sementara kandungan mineral seperti kalsium ada hanya dalam jumlah kecil. Menurut Irfandi (2005), kandungan kalsium yang dimiliki oleh nanas sebesar $18 \mathrm{mg} / 100 \mathrm{~g}$. Nilai kandungan kalsium tersebut sangat kecil sehingga dibutuhkan penambahan bahan lain yang memiliki kandungan kalsium yang tinggi untuk meningkatkan nilai kandungan kalsium selai nanas. Menurut Dalimartha dan Mooryati (1999), kalsium merupakan mineral yang paling banyak terdapat di dalam tubuh. Kalsium bersama fosfor membentuk matriks 
tulang, pembentukan ini dipengaruhi pula oleh vitamin $\mathrm{D}$, membantu proses penggumpalan darah dan mempengaruhi penerimaan rangsang pada otot syaraf (Marsetyo dan Kartasapoetra, 1991).

Upaya yang dapat dilakukan untuk meningkatkan kandungan kalsium pada selai nanas adalah dengan melakukan penambahan sawi hijau. Sawi hijau merupakan sayuran yang sering dijumpai didalam kehidupan sehari-hari dan harganya terjangkau. Sawi hijau memiliki kadar kalsium lebih tinggi yaitu 220,5mg/100g (Anonim,1979) dibandingkan nanas yang hanya $18 \mathrm{mg} / 100 \mathrm{~g}$ (Irfandi,2005), dengan demikian diharapkan penambahan sawi hijau mampu meningkatkan kandungan kalsium pada selai. Pemanfaatan sawi hijau menjadi produk olahan masih sangat terbatas karena kebanyakan masyarakat kurang menyukai sayuran (Winarno, 1987). Perpaduan nanas dan sawi hijau menjadi selai akan menjadi produk yang dapat memenuhi kebutuhan kalsium tubuh sekaligus dapat mengatasi ketidaksukaan pada sayuran. Penambahan sawi hijau berpengaruh terhadap karakteristik selai, untuk itu perlu diteliti berapakah perbandingan terbaik antara nanas dan sawi hijau agar didapatkan selai dengan karakteristik terbaik yang disukai oleh panelis.

\section{METODE PENELITIAN}

\section{Tempat dan Waktu penelitian}

Penelitian ini dilakukan di Laboratorium Analitik Universitas Udayana Laboratorium Pengolahan Pangan dan Laboratorium Analisis Pangan,Fakultas Teknologi Pertanian Universitas Udayana, Jalan PB Sudirman,
Denpasar, Bali. Penelitian ini berlangsung selama 2 bulan, dimulai dari bulan November 2016 sampai dengan Januari 2017.

\section{Alat dan Bahan}

Adapun alat yang digunakan dalam penelitian ini, antara lain: blender, pisau, talenan, saringan, wajan stainless steel, pengaduk kayu, kompor gas, sendok sayur, baskom, botol selai dengan penutup, hand refraktometer (Labo), $\mathrm{pH}$ meter (Rohs), alat pengukur waktu, kertas saring, corong, viscometer (Brookfield), labu takar, gelas ukur, cawan porselin, desikator, spektrofotometer (Tharmo), beaker glass (Pyrex), pipet tetes, pipet mikro (Ika), timbangan analitik, erlenmeyer, oven. pinset.

Bahan yang digunakan dalam penelitian ini, antara lain : nanas (bogor) dengan indeks kematangan 3 dibeli di pasar Badung Denpasar, sawi hijau (caisim) dibeli di pasar Badung Denpasar, asam sitrat, pektin, gula pasir, kertas whatman 42, alumunium foil, air, plastik, akuades, natrium karbonat anhidrat, garam Rochelle, natrium bikarbonat, natrium sulfat anhidrat, cupri sulfat, arsenomolibidat.

\section{Rancangan Penelitian}

Penelitian ini dilakukan dengan menggunakan Rancangan Acak Lengkap (RAL) dengan perlakuan perbandingan nanas dan sawi hijau terdiri dari 5 perlakuan sebagai berikut:

$$
\begin{array}{ll}
\text { P0 } & \text { : Nanas } 100 \% \text {, sawi hijau } 0 \% \\
\text { P1 } & \text { : Nanas } 95 \% \text {, sawi hijau } 5 \% \\
\text { P2 } & \text { : Nanas } 90 \% \text {, sawi hijau } 10 \% \\
\text { P3 } & \text { : Nanas } 85 \% \text {, sawi hijau } 15 \%
\end{array}
$$


P4 : Nanas 80\%, sawi hijau 20\%

Percobaan diulang sebanyak tiga kali ulangan, sehingga diperoleh 15 unit percobaan.

Data yang diperoleh dianalisis dengan ANOVA dan apabila terdapat pengaruh perlakuan, maka akan diuji lanjut dengan uji Duncan. (Steel dan Torrie, 1993).

\section{Parameter yang diamati}

Parameter yang diamati pada penelitian ini meliputi kadar air (AOAC,1995), kadar gula (Sudarmadji et.al,1997), kadar kalsium (SNI3554,2015), total padatan terlarut (AOAC,1995), viskositas (Jacobs, 1958), pH (Sudarmadji et al,1997) dan evaluasi sensoris menggunakan uji hedonik (kesukaan) terhadap tekstur, warna, aroma, rasa dan penerimaan keseluruhan sedangkan uji skoring untuk tekstur, warna dan aroma. (Soekarto, 1985).

\section{Pelaksanaan Penelitian}

\section{Pembuatan Selai}

Formulasi dari bahan baku pembuatan selai pada penelitian ini adalah $75 \mathrm{~g}$ gula pasir, 1,5 $\mathrm{g}$ pektin, 0,75 asam sitrat dan untuk perbandingan nanas dan sawi hijau yang digunakan adalah P0 100\%:0\%, P1 95\%:5\%, P2 90\%:10\%, P3 85\%:15\% dan P4 80\%:20\%. (Turmala et al., 2013 yang telah dimodifikasi). Pembuatan selai nanas dan sawi hijau ini diawali dengan sortasi bahan. Nanas dikupas, dihilangkan kulit dan matanya kemudian dipotong dan ditimbang sesuai dengan perlakuan, selanjutnya dihaluskan dengan cara diblender. Sawi hijau dicuci dan dihilangkan batangnya kemudian ditimbang. Sawi hijau yang telah ditimbang kemudian diblansir dengan suhu $70^{\circ} \mathrm{C}$ selama 5 menit, selanjutnya diblender. Bubur nanas dan sawi hijau kemudian dicampur dengan gula pasir 50\%. Pemasakan selai dengan suhu $80^{\circ} \mathrm{C}$ dan dilakukan pencampuran dengan pektin $1 \%$ dan asam sitrat $0,5 \%$ sambil diaduk hingga kental. Cara mengetahui kental atau belum, dengan cara mengambil selai dengan sendok kemudian diteteskan apabila sudah tidak menetes berarti sudah kental (spoon test) (Fachruddin, 1997). Diagram alir proses pembuatan selai dapat dilihat pada Gambar 1. 


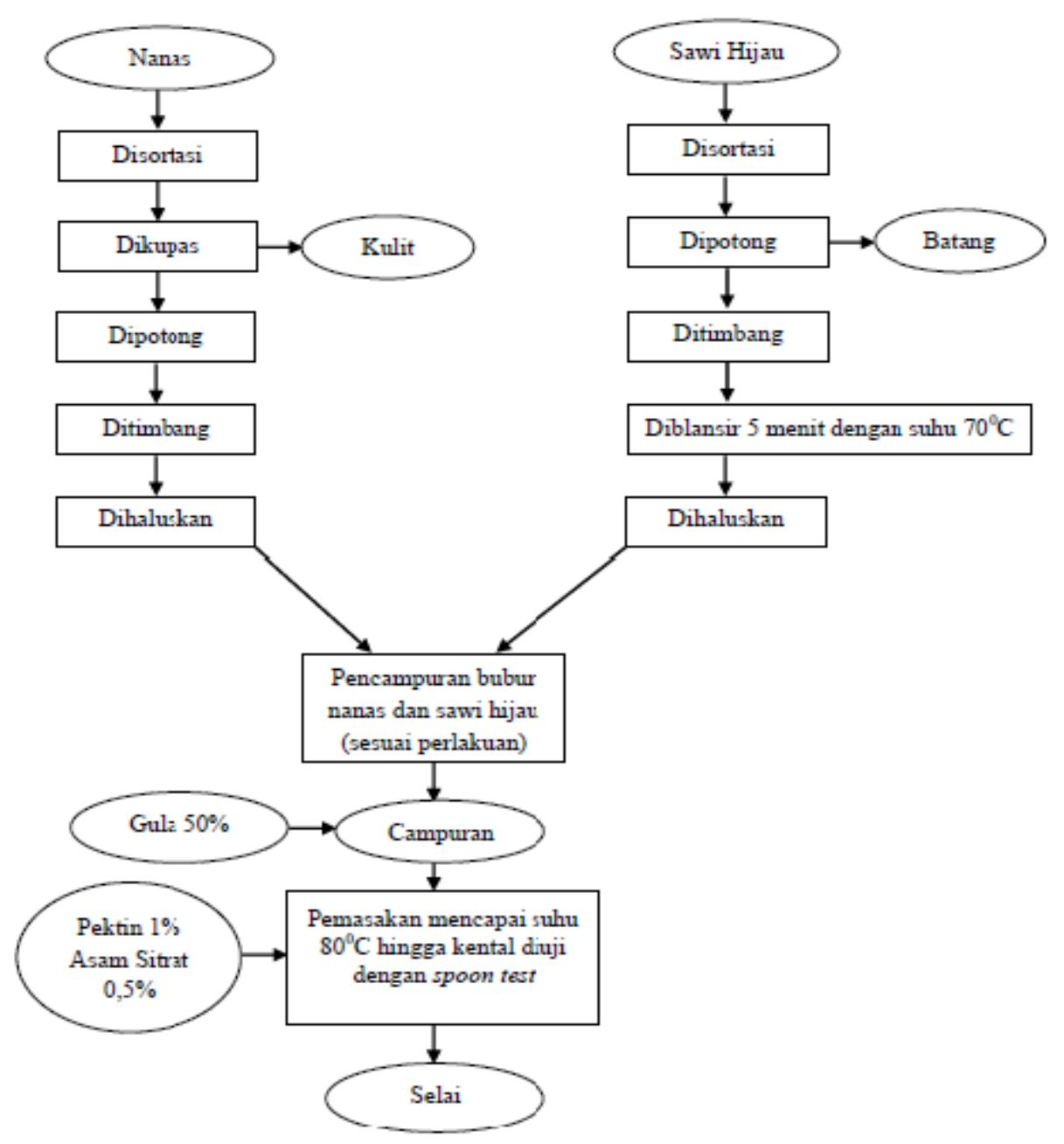

Gambar 1. Diagram Alir Proses Pembuatan Selai. (Turmala et al., 2013 yang telah dimodifikasi)

\section{HASIL DAN PEMBAHASAN}

Hasil analisis kadar air, total gula, kadar kalsium, total padatan terlarut, viskositas, dan $\mathrm{pH}$ dari selai perbandingan nanas dan sawi hijau dapat dilihat pada Tabel 1.

\section{Kadar Air}

Dari hasil analisis ragam (Tabel 1) menunjukkan bahwa perbandingan nanas dan sawi hijau berpengaruh nyata terhadap kadar air selai $(\mathrm{P}<0,05)$ dengan kisaran antara 23,42\%-28,30\%. Kadar air tertinggi diperoleh P4 (nanas 80\%, sawi hijau 20\%) sebesar $28,30 \%$ sedangkan yang terendah pada perlakuan P0 (nanas 100\%, sawi hijau 0\%) yaitu sebesar $23,42 \%$. Semakin banyak sawi hijau yang digunakan kadar air selai semakin tinggi. Menurut Rukmana (2002), sawi hijau memiliki kandungan air yang tinggi mencapai 95\%. Dengan demikian perlakuan dengan perbandingan jumlah sawi hijau yang tinggi akan meningkatkan kadar air dari selai yang dihasilkan. Proses pemanasan tidak banyak mempengaruhi kadar air selai karena dengan kadar air bahan yang tinggi maka kadar air selai yang dihasilkan juga tinggi. Kadar air selai sudah sesuai dengan Standar Nasional 
Indonesia (SNI) karena kadar air maksimum selai menurut SNI adalah 35\% (SNI -3746, 2008).

\section{Total Gula}

Hasil analisis ragam pada Tabel 1 menunjukkan bahwa perbandingan nanas dan sawi hijau tidak berpengaruh nyata terhadap total gula $(\mathrm{P}>0,05)$. Hasil analisis total gula pada penelitian ini berkisar antara 51,3\%-
$64,99 \%$. Tidak adanya pengaruh perbandingan nanas dan sawi hijau pada total gula karena jumlah gula yang ditambahkan pada setiap perlakuan sama. Syarat mutu selai adalah harus memiliki kandungan gula minimum 55\% (SNI3746 , 2008) itu artinya 4 perlakuan perbandingan pada penelitian ini sudah memenuhi Standar Nasional Indonesia (SNI) selai yaitu P0, P1, P2 dan P3.

Tabel 1. Hasil analisis selai nanas dan sawi hijau.

\begin{tabular}{ccccccc}
\hline Perlakuan & $\begin{array}{c}\text { Kadar } \\
\text { Air (\%) }\end{array}$ & $\begin{array}{c}\text { Total } \\
\text { Gula (\%) }\end{array}$ & $\begin{array}{c}\text { Kadar } \\
\text { Kalsium } \\
(\mathbf{m g} / \mathbf{1 0 0 g r})\end{array}$ & $\begin{array}{c}\text { Total } \\
\text { Padatan } \\
\text { Terlarut } \\
\text { (\%)rix) }\end{array}$ & $\begin{array}{c}\text { Viskositas } \\
\text { (cps) }\end{array}$ & pH \\
\hline P0 & $23,42 \mathrm{c}$ & 64,99 & $3,108 \mathrm{e}$ & $63,83 \mathrm{a}$ & $99733 \mathrm{a}$ & 4,50 \\
P1 & $25,11 \mathrm{bc}$ & 60,5 & $4,591 \mathrm{~d}$ & $61 \mathrm{~b}$ & $85713 \mathrm{ab}$ & 4,62 \\
P2 & $25,58 \mathrm{bc}$ & 57,45 & $6,176 \mathrm{c}$ & $59,15 \mathrm{c}$ & $64580 \mathrm{bc}$ & 4,65 \\
P3 & $27,28 \mathrm{ab}$ & 55,03 & $7,745 \mathrm{~b}$ & $57,98 \mathrm{c}$ & $58733 \mathrm{bc}$ & 4,65 \\
P4 & $28,30 \mathrm{a}$ & 51,3 & $9,315 \mathrm{a}$ & $56,5 \mathrm{~d}$ & $55047 \mathrm{c}$ & 4,63 \\
\hline
\end{tabular}

Keterangan: Nilai rata-rata yang diikuti oleh huruf yang berbeda pada kolom yang sama menunjukkan perbedaan yang sangat nyata $(\mathrm{P}<0,01)$.

\section{Kadar Kalsium}

Berdasarkan hasil analisis ragam (Tabel 1) menunjukkan bahwa perbandingan nanas dan sawi hijau berpengaruh sangat nyata $(\mathrm{P}<0,01)$ terhadap kadar kalsium selai. Tabel 1. menunjukkan Hasil analisis kadar kalsium berkisar antara 3,108 mg/100g-9,315 mg/100g. Selai dengan perlakuan P4 (nanas $80 \%$ : sawi hijau 20\%) mendapat nilai rata-rata kadar kalsium tertinggi nilai $9,315 \mathrm{mg} / 100 \mathrm{~g}$, sedangkan nilai terendah pada perlakuan P0 (nanas 100\%, sawi hijau 0\%) yaitu sebesar $3,108 \mathrm{mg} / 100 \mathrm{~g}$. Hal ini menunjukan semakin banyak sawi yang digunakan, kadar kalsiumnya semakin tinggi karena sawi memiliki kandungan kalsium yang jauh lebih tinggi dibandingkan dengan nanas yaitu 220,5mg/100g (Anonim,1979) sedangkan nanas hanya $18 \mathrm{mg} / 100 \mathrm{~g}$ (Irfandi, 2005).

\section{Total Padatan Terlarut}

Pada hasil analisis ragam menunjukkan bahwa perbandingan nanas dan sawi hijau sangat berpengaruh nyata $(\mathrm{P}<0,01)$ terhadap total padatan terlarut selai (Tabel 1). Nilai ratarata total padatan terlarut selai berkisar antara $56,5 \%$ brix-63,83\%brix, total padatan terlarut tertinggi diperoleh P0 (nanas 100\%, sawi hijau 0\%) 63,83\%brix sedangkan yang terendah P4 (nanas $80 \%$, sawi hijau 20\%) yaitu sebesar 
56,5 \%brix. Penggunaan nanas yang semakin tinggi menghasilkan total padatan terlarut yang semakin tinggi, nanas memiliki kandungan gula yang lebih tinggi dari sawi hijau (Irfandi, 2005). Gula yang terkandung dalam nanas yaitu glukosa $2,32 \%$ fruktosa $1,42 \%$ dan sukrosa $7,89 \%$. Kandungan total padatan terlarut suatu bahan meliputi gula reduksi, gula non reduksi, asam organik, pektin dan protein (Desrosier, 1988).

\section{Viskositas}

Hasil analisis ragam menunjukkan bahwa perbandingan nanas dan sawi hijau berpengaruh nyata $(\mathrm{P}<0,05) \quad$ terhadap viskositas selai. Tabel 1 menunjukkan bahwa hasil analisis viskositas berkisar antara 55047 cps-99733 cps. P0 memiliki nilai rata-rata tertinggi yaitu 99733 cps sedangkan P4 mendapat nilai terendah yaitu 55047 cps. Semakin tinggi penggunaan nanas maka semakin besar pula gel yang terbentuk karena nanas memiliki kandungan pektin 1,0 - 1,2 \% / 100 g (Hidayat,2008) sehingga selai yang dihasilkan lebih kental. Menurut Yuliani (2011) pektin mempunyai sifat yang dapat membentuk gel, semakin banyak pektin makin keras gel yang dibentuk. Menurut Desrosier (1988), terbentuknya gel ditentukan oleh banyaknya konsentrasi pektin.

pH

Hasil analisis ragam pada Tabel 1 menunjukkan bahwa perbandingan nanas dan sawi hijau tidak berpengaruh nyata $(\mathrm{P}>0,05)$ terhadap $\mathrm{pH}$ selai. Nilai keasaman $(\mathrm{pH})$ selai pada penelitian ini berkisar antara 4,50 sampai 4,65. Hal ini menunjukkan bahwa perbandingan jumlah nanas dan sawi hijau tidak mempengaruhi $\mathrm{pH}$ selai. Jumlah perbandingan nanas tidak mempengaruhi $\mathrm{pH}$ dari selai yang dihasilkan karena jumlah asam sitrat yang ditambahkan sama.

\section{Evaluasi Sensoris}

Hasil evaluasi sensoris kesukaan tekstur, warna, aroma, rasa dan penerimaan keseluruhan terhadap selai nanas dan sawi hijau dapat dilihat pada Tabel 2.

Tabel 2. Hasil evaluasi sensoris kesukaan selai nanas dan sawi hijau.

\begin{tabular}{cccccc}
\hline Perlakuan & Tekstur & Warna & Aroma & Rasa & $\begin{array}{c}\text { Penerimaan } \\
\text { Keseluruhan }\end{array}$ \\
\hline P0 & $3,13 \mathrm{c}$ & $4,2 \mathrm{a}$ & $3,47 \mathrm{~b}$ & $3,53 \mathrm{~b}$ & $3,2 \mathrm{~b}$ \\
P1 & $4,2 \mathrm{~b}$ & $3,73 \mathrm{a}$ & $3,67 \mathrm{~b}$ & $4,2 \mathrm{a}$ & $4,6 \mathrm{a}$ \\
P2 & $4,93 \mathrm{a}$ & $4,13 \mathrm{a}$ & $4,33 \mathrm{a}$ & $4,6 \mathrm{a}$ & $4,53 \mathrm{a}$ \\
P3 & $3,13 \mathrm{c}$ & $2,4 \mathrm{~b}$ & $3,33 \mathrm{~b}$ & $2,8 \mathrm{c}$ & $2,87 \mathrm{~b}$ \\
P4 & $2,87 \mathrm{c}$ & $1,6 \mathrm{c}$ & $2,4 \mathrm{c}$ & $2,27 \mathrm{c}$ & $2,07 \mathrm{c}$ \\
\hline
\end{tabular}

Keterangan: Huruf yang berbeda di belakang nilai rata-rata pada kolom yang sama menunjukkan perbedaan yang sangat nyata $(\mathrm{P}<0,01)$. 
Hasil evaluasi sensoris skoring tekstur, warna dan aroma terhadap selai nanas dan sawi hijau dapat dilihat pada Tabel 3.

\section{Tekstur}

Selai yang baik harus memiliki daya oles yang baik artinya tidak terlalu encer (Abidanbita, 2010). Hasil analisis ragam menunjukkan bahwa perbandingan nanas dan sawi hijau berpengaruh sangat nyata $(\mathrm{P}<0,01)$ terhadap tekstur selai (Tabel 2 dan 3). Nilai rata-rata penilaian panelis secara hedonik dan skoring terhadap tekstur selai dapat dilihat pada Tabel 2 dan Tabel 3. Nilai uji kesukaan tekstur berkisar antara 2,87 (biasa) yang dihasilkan pada perlakuan P4 sampai 4,93 (sangat suka) yang dihasilkan pada perlakuan P2. Nilai uji skoring tekstur berkisar antara 1,4 (sangat kental) yang dihasilkan pada perlakuan P4 hingga 4,53 (kental) yangdihasilkan pada perlakuan P2. Tekstur selai yang disukai para panelis adalah yang kental. Hasil uji hedonik para panelis pada perlakuan nanas $90 \%$ dan sawi hijau $10 \%(\mathrm{P} 2)$ selai yang dihasilkan memiliki tekstur yang kental.

Tabel 3. Hasil evaluasi sensoris skoring selai nanas dan sawi hijau

\begin{tabular}{cccc}
\hline Perlakuan & Tekstur & Warna & Aroma \\
\hline P0 & $2,4 \mathrm{~d}$ & $4,6 \mathrm{c}$ & $6 \mathrm{~b}$ \\
P1 & $3,87 \mathrm{~b}$ & $5,87 \mathrm{~b}$ & $5,8 \mathrm{~b}$ \\
P2 & $4,53 \mathrm{a}$ & $6,67 \mathrm{a}$ & $6,6 \mathrm{a}$ \\
P3 & $3,2 \mathrm{c}$ & $3,4 \mathrm{~d}$ & $2,47 \mathrm{c}$ \\
P4 & $1,4 \mathrm{e}$ & $1 \mathrm{e}$ & $1,47 \mathrm{~d}$ \\
\hline
\end{tabular}

Keterangan: Huruf yang berbeda di belakang nilai rata-rata pada kolom yang sama menunjukkan perbedaan yang sangat nyata $(\mathrm{P}<0,01)$.

\section{Warna}

Hasil analisis ragam menunjukkan bahwa perbandingan nanas dan sawi hijau berpengaruh sangat nyata $(\mathrm{P}<0,01)$ terhadap warna selai (Tabel 2 dan 3). Nilai rata-rata uji kesukaan warna berkisar antara 1,6 (tidak suka) yang dihasilkan pada perlakuan P4 sampai 4,2 (suka) yang dihasilkan pada perlakuan P0. Nilai uji skoring warna berkisar antara 1 (sangat hijau kecoklatan) hingga 6,67 (agak tidak hijau kecoklatan). Nilai terendah didapat P4 sebesar 1 (sangat hijau kecoklatan) sedangkan tertinggi P2 sebesar 6,67 (agak tidak hijau kecoklatan).

\section{Aroma}

Nilai rata-rata penilaian panelis secara hedonik dan skoring terhadap aroma selai dapat dilihat pada Tabel 2 dan Tabel 3. Hasil analisis ragam menunjukkan bahwa perbandingan nanas dan sawi hijau berpengaruh sangat nyata $(\mathrm{P}<0,01)$ terhadap aroma selai (Tabel 2 dan 3). Nilai uji kesukaan aroma berkisar antara 2,4 (tidak suka) yang dihasilkan pada perlakuan P4 sampai 4,33 (suka) yang dihasilkan pada perlakuan P2. Nilai terendah uji skoring didapat P4 1,47 (sangat khas sawi hijau) sedangkan yang tertinggi P2 6,6 (agak khas sawi hijau). Perbandingan nanas dan sawi hijau berpengaruh sangat nyata terhadap aroma selai. 


\section{Rasa}

Hasil analisis ragam menunjukkan bahwa perbandingan nanas dan sawi hijau berpengaruh sangat nyata $(\mathrm{P}<0,01)$ terhadap rasa selai (Tabel 2). Nilai rata-rata peniliaian panelis terhadap rasa selai dapat dilihat pada Tabel 2. Nilai terendah didapat P4 2,27 (biasa) sedangkan yang tertinggi P2 4,6 (sangat suka).

\section{Penerimaan Keseluruhan}

Hasil analisis ragam menunjukkan bahwa perbandingan nanas dan sawi hijau terhadap selai berpengaruh sangat nyata $(\mathrm{P}<0,01)$ terhadap penerimaan keseluruhan selai dalam uji kesukaan. Nilai terendah didapat oleh P4 2,07 (tidak suka) sedangkan yang tertinggi P1 4,6 (sangat suka). Perlakuan yang paling disukai secara keseluruhan adalah P1 dengan perbandingan nanas $95 \%$ dan sawi hijau 5\%.

\section{KESIMPULAN DAN SARAN}

\section{Kesimpulan}

Berdasarkan hasil penelitian dapat disimpulkan sebagai berikut :

Perbandingan nanas dan sawi hijau berpengaruh terhadap kadar air, kadar kalsium, total padatan terlarut, viskositas, tekstur, warna, aroma, rasa, dan penerimaan keseluruhan, dan sawi hijau tidak berpengaruh terhadap total gula dan $\mathrm{pH}$. Nanas $90 \%$ : sawi hijau 10\% memiliki karakteristik selai terbaik, dengan kadar air 25,58\%, total gula 57,45\%, kadar kalsium $6,176 \mathrm{mg} / \mathrm{g}$, total padatan terlarut 59,15\%brix, viskositas $64580 \mathrm{cps}, \mathrm{pH}$ 4,65 , tekstur sangat suka, warna suka, aroma suka, rasa sangat suka dan keseluruhan sangat disukai oleh panelis.

\section{Saran}

Berdasarkan penelitian diatas disarankan untuk melakukan penelitian lebih lanjut tentang umur simpan selai dengan penggunaan nanas $90 \%$ : sawi hijau $10 \%$.

\section{DAFTAR PUSTAKA}

Abidanbita. 2010. Teknologi Pemekatan (Pembuatan Jam/Selai, Jely dan Saus Tomat) Part I. http://abidanbita.multiply.com diakses 9 Juni 2016

Anonim 1979. Direktorat Gizi. Daftar Komposisi Nutrisi Bahan Makanan. Departemen Kesehatan RI.

AOAC, 1995. Official Methods of Analysis of The Association of Analytical Chemists, Washington D.C.

Dalimartha, Setiawan, dan R.A. Mooryati Soedibyo. 1999. Awet Muda dengan Tumbuhan Obat Diet Suplemen. Trubus Agriwidya. Jakarta

Desrosier, N. W., 1988. Teknologi Pengawetan Pangan. Penerjemah M. Muljohardjo. UI-Press, Jakarta.

Fachruddin,1997.Membuat Aneka Selai . Kanisius. Yogyakarta.

Hidayat P., 2008. Teknologi Pemanfaatan Serat Daun Nanas sebagai Alternatif Bahan Baku Tekstil., Teknoin, Vol 13, 31-35.

Kartika P.N dan Fitri C.N. 2015. Studi Pembuatan Osmodehidrat Buah Nanas (Ananas Comosus L. Merr): Kajian Konsentrasi Gula Dalam Larutan Osmosis dan Lama Perendaman. Jurnal Pangan dan Agroindustri Vol. 3 No 4 p. 1345-1355.

Irfandi. 2005. Karakteristik Morfologi Lima Populasi Nanas (Ananas comocuc (L.)Merr.).

http://repostory.ipb.ac.id/bitstream/handl e/123456789/12566/A05irf.pdf. Diakses tanggal 1 Oktober 2016

Jacobs, M. B. 1958. The Chemistry and Technology of Food and Food Product. Interscience Publishers. New York

Marsetyo, H, dan Kartasapoetra, G, 1991. Ilmu Gizi (Korelasi Gizi, Kesehatan dan 
Produktivitas Kerja). Rineka Cipta. Jakarta.

Palupi S., HamidahS.dan Purwati S. 2009. Peningkatan Produktivitas Hasil Olahan Salak Melalui Diversifikasi Sekunder untuk Mendukung Pengembangan Kawasan Agropoitan. Jurnal Inotek, Vol.13, No.1. Universitas Negeri Yogyakarta. Yogyakarta.

Rukmana, 2002. Bertanam Petsai dan Sawi. Kanisius, Yogyakarta.

SNI-3554. 2015. Metode Uji Logam Secara Inductively Coupled Plasma (ICP). Badan Standarisasi Nasional. Jakarta. SNI-3746. 2008. Selai Buah. Badan Standarisasi Nasional, Jakarta.

SNI-3746. 2008. Selai Buah. Badan Standarisasi Nasional, Jakarta

Soekarto, 1985. Penilaian Organoleptik untuk Industri Pangan dan Hasil Pertnian. Pusat Pengembangan Teknologi Pangan, IPB, Bogor.
Steel, R. G. D. dan J. H. Torrie. 1993. Prinsip dan Prosedur Statistik. Penerjemah Bambang Sumantri. PT. Gramedia Pustaka Utama, Jakarta.

Sudarmadji, S., B. Haryono, Suhardi. 1997. Prosedur Analisa untuk Bahan Makanan dan Pertanian. Penerbit Liberty. Yogyakarta

Turmala, E., Hervelly, N.K. Wardhana. 2013. Kajian Pengaruh Konsentrasi Gula Dan Konsentrasi Pektin Terhadap Karakteristik Selai Buah Campolay (Pouteria Campechiana). Hasil Penelitian Fakultas Teknik Universitas Pasundan. Bandung.

Winarno, F.G., 1987. Gizi dan Makanan. Pustaka Sinar Harapan. Jakarta.

Yuliani. 2011. Karakteristik Selai Tempurung Kelapa Muda. File Seminar Nasional Teknik Kimia. Teknik Kimia Politeknik Ujung Pandang. Yogyakarta. 